\title{
International palliative care research priorities: A systematic review
}

\author{
Felicity Hasson ${ }^{1 *}$ (D), Emma Nicholson², Deborah Muldrew ${ }^{1}$, Olufikayo Bamidele ${ }^{3}$, Sheila Payne ${ }^{4}$ and Sonja Mcllfatrick ${ }^{1}$
}

\begin{abstract}
Background: There has been increasing evidence and debate on palliative care research priorities and the international research agenda. To date, however, there is a lack of synthesis of this evidence, examining commonalities, differences, and gaps. To identify and synthesize literature on international palliative care research priorities originating from Western countries mapped to a quality assessment framework.

Methods: A systematic review of several academic and grey databases were searched from January 2008-June 2019 for studies eliciting research priorities in palliative care in English. Two researchers independently reviewed, critically appraised, and conducted data extraction and synthesis.

Results: The search yielded 10,235 articles (academic databases, $n=4108$; grey literature, $n=6127$ ), of which ten were included for appraisal and review. Priority areas were identified: service models; continuity of care; training and education; inequality; communication; living well and independently; and recognising family/carer needs and the importance of families. Methodological approaches and process of reporting varied. There was little representation of patient and caregiver driven agendas. The priorities were mapped to the Donabedian framework for assessing quality reflecting structure, process and outcomes and key priority areas.

Conclusions: Limited evidence exists pertaining to research priorities across palliative care. Whilst a broad range of topics were elicited, approaches and samples varied questioning the credibility of findings. The voice of the care provider dominated, calling for more inclusive means to capture the patient and family voice. The findings of this study may serve as a template to understand the commonalities of research, identify gaps, and extend the palliative care research agenda.
\end{abstract}

Keywords: Palliative care, research priorities, Consensus, International. Systematic review

\section{Background}

Globally 40 million people are estimated to need palliative care each year, yet it has been estimated that only $14 \%$ are in receipt of such care [1]. Worldwide reports forecast that demand for palliative care is set to escalate over the next several decades, in response to changing demographics, longer disease trajectories and greater co-morbidity $[2,3]$. Although palliative care has been advocated in global policy $[4,5]$ and viewed as a basic human right $[6,7]$, the proportion of research funding allocated is historically small $[8,9]$, resulting in a considerably under-developed evidence base [8]. For example, in the UK in 2013 the National Cancer

\footnotetext{
* Correspondence: f.hasson@ulster.ac.uk

${ }^{1}$ Institute of Nursing and Health Research, School of Nursing, Ulster University, Shore Road, Newtownabbey BT37 OQB, Northern Ireland Full list of author information is available at the end of the article
}

Research Institute allocated $0.61 \%$ of its research budget to palliative and end of life care [10].

Priority setting is recognised as an essential task to help direct finite resources to support research $[2,11]$. Such exercises are considered integral to the research process to guide and stimulate funding, fuel debate, and to strengthen the role of stakeholders in establishing the research agenda [12]. Ultimately, such approaches should help to underpin the development and improvement of palliative care for the patient and caregiver. In palliative care, a range of priority setting processes have been undertaken nationally across different countries and internationally by various organisations, networks and individuals [13-15]. A large proportion have been developed specific to disease type, for example, in head and neck cancer [16], dementia [17], intellectual disability [18] and generic palliative care [19] to name but a

(c) The Author(s). 2020 Open Access This article is distributed under the terms of the Creative Commons Attribution 4.0 International License (http://creativecommons.org/licenses/by/4.0/), which permits unrestricted use, distribution, and 
few. Priorities have also been identified by care setting [20, 21], patient demographic characteristics [22, 23], discipline focus [24, 25], and according to the specific components of palliative care such as pain [26] and spiritual care [27].

While it is important that the palliative care needs of specific disease groups and populations are considered and addressed, to enable transferable learning establishing global research priorities can provide a coherent research agenda, highlighting complex multi-faceted global problems [28, 29]. Moreover, such exercises can provide a platform for multidisciplinary research aiding the alignment of scarce global resources, so that important directions for future research can be met [30]. However, whilst global priorities provide a platform from which to understand the commonalities of palliative care, they underscore the complexity and unique characteristics of the landscape within which palliative care operates. For example, Zaman et al. [31] highlights the challenges of transferring ideals of palliative care between developed and developing countries, instead arguing for the need for global common denominators to be identified to enable culturally appropriate provision to be established.

Moreover mismatches between patient and health professional priorities have been reported [32]. This has spurred greater efforts to include patients and caregivers in the palliative care research agenda to ensure relevancy to their needs $[33,34]$. The need to increase the value of resources invested in research is critical, and research that does not address the needs and concerns of its end users may be considered wasted [35] .

A preliminary search of the literature for previous systematic reviews of palliative care research priorities yielded no results. The need to establish the progress, and inform the development, of an international coordinated approach of palliative care research priorities is required to enhance transparency, identify and prioritise research topics, and ensure patients and caregivers are at the centre of that agenda. Therefore, this study aimed to identify and synthesize literature on international palliative care research priorities, originating mainly from Western countries, mapped to the Donabedian framework [36]. Critically, the review also synthesised the approaches adopted, stakeholders involved and the jurisdictions in which the priorities have been developed. Using thematic synthesis [37], a set of high-level research priorities have been developed to provide the basis for a strategic international framework for palliative care research going forward.

\section{Methods}

\section{Study design}

A systematic review of research priorities in palliative care was undertaken and guided by the PRISMA statement for reporting systematic reviews [38] .

\section{Search strategy}

A systematic search of databases from health sciences, medicine, and psychology was undertaken in August 2017 in conjunction with a subject librarian. Six databases were searched: Cumulative Index of Nursing and Allied Health Literature (CINAHL), Excerpta Medica database (EMBASE), PubMed, SCOPUS, Web of Science, and PsycINFO. Grey literature was identified via ProQuest Dissertations and Theses, CareSearch grey literature, James Lind Alliance Website, Lenus, and the Palliative Hub of the All Ireland Institute of Hospice and Palliative Care. A further search of the grey literature was conducted on the following sites in April and May 2019: OpenGrey, European Association of Palliative Care (EAPC) conferences, Australian and New Zealand Society of Palliative Medicine and Google.

Key words were identified through the titles, abstracts, and indexed phrases of relevant articles from a preliminary search of PubMed and CINAHL. Indexed terms from the selected databases were identified and included in the search terms for these specific databases (Table 1). Articles were limited by publication date (January 2008June 2019) and language (English). Subsequently, indexed terms (e.g., CINAHL headings, mesh terms) from the selected databases were identified and included in the search terms for these databases

\section{Screening}

The search yielded 10,235 articles from which $2007 \mathrm{du}$ plicates were removed (Fig. 1). Two reviewers (EN and FH) uploaded titles and abstracts of the remaining 8318 papers into Covidence for initial screening, of which 8252 were considered irrelevant and excluded. Four reviewers (EN, DM, FH and $\mathrm{OB})$ screened the full texts of the remaining 66 articles against the review's inclusion/ exclusion criteria (Table 2).

Ten studies were eligible, and they were included for quality appraisal (see Fig. 1). Any conflict of opinion regarding which article to include or exclude was resolved through discussion among the reviewers. If no agreement could be reached between the reviewers, a fifth reviewer (SM) mediated.

Table 1 Search terms used in the systematic review (including an example of the Mesh terms from the search of PubMed)

"Palliative care" OR "end of life" OR "terminal care" OR "Critical care" OR hospice OR "terminally ill" OR "Palliative Care"[Majr] OR "Terminal Care"[Majr:NoExp] OR "Hospice Care"[Majr] OR "Terminally III"[Mesh] AND

"Research priorit*" OR "Health services research" OR "Research Agenda" OR "Research quest*" OR "Research Gap*" OR "Knowledge gap*" OR "Research initiative*" OR "Research recommendation*" OR "priority areas of research" OR "Evidence Base" OR "Research Subject*" OR "Policyrelevant research" OR "Research program*" OR "Research direction*" OR "Recommendations for research" OR "High-quality research" OR "Research"[Majr:NoExp] OR "Health Services Research"[Mesh:NoExp] 


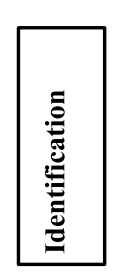

Records identified through database search $(n=4108)$

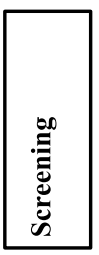

No. of duplicates removed $(\mathrm{n}=2007)$
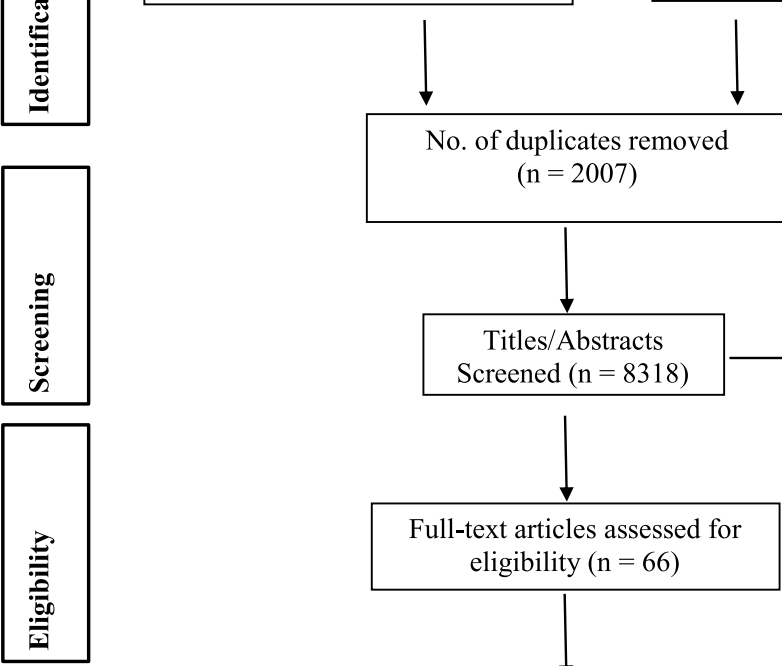

Additional Records identified through other sources: Grey literature $(n=6127)$
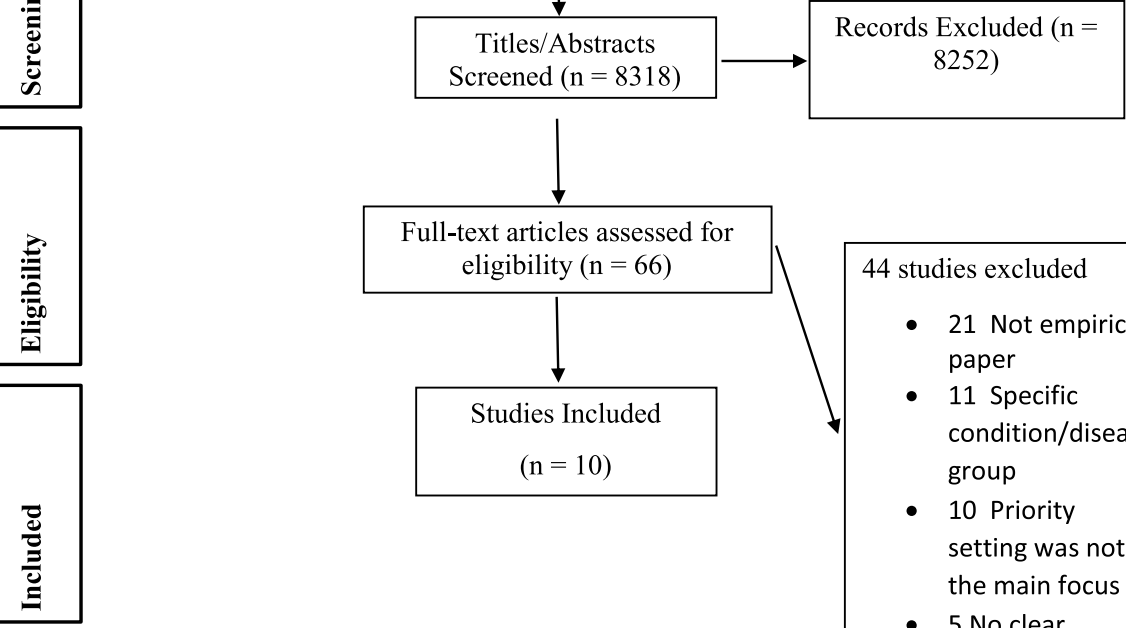

Full-text articles assessed for eligibility $(n=66)$

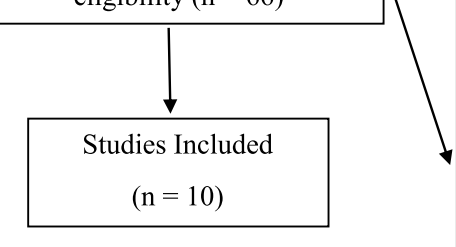

44 studies excluded

- 21 Not empirical paper

- 11 Specific condition/disease group

- 10 Priority setting was not the main focus

- 5 No clear research priorities

- 2 Wrong setting

- 1 Wrong patient population

- 6 Insufficient details (abstract only, full text unavailable)

Fig. 1 PRISMA Flow Diagram

Table 2 Inclusion and Exclusion criteria for the systematic review

\begin{tabular}{l} 
Inclusion Criteria \\
\hline Studies that directly elicited and identified research priorities for \\
palliative care (including patients/carers, healthcare providers, \\
policymakers, and researchers) and parentheses \\
Methods of identifying priorities could include (but not limited to) \\
surveys, qualitative studies, consensus methods (Delphi survey, \\
nominal group technique), and workshops
\end{tabular}
Exclusion Criteria

Studies that have considered research priorities relating to specific aspect of palliative care (e.g., spiritual, medical)

Studies assessing priorities for practice and policy (quality indicators); nonresearch articles (policy documents, clinical guidelines, editorials, commentaries); reports of a conference, workshop or meeting that did not include information about the participants and methods; and basic science research, epidemiological studies, guidelines, and economic evaluations were excluded. 


\section{Quality appraisal and risk of Bias}

Quality appraisal was undertaken to gain an understanding of the results and level of confidence in the findings. The quality, methodological rigour, and risk of bias of the ten studies included in the final review were assessed using the Joanna Briggs Institute (JBI) Critical Appraisal Tools [39]. JBI critical appraisal tools were selected based on their appropriateness to the methodology in the papers. The qualitative research tool [40] was utilised for papers using workshops, the systematic review tool [41] was used for evidence reviews, and the cross-sectional research tool [42] for research using surveys and questionnaires. To prevent the introduction of bias and enhance transparency, four studies [21, 43-45], adopting multiple methods and consensus methods, were not subject to quality appraisal due to a lack of specific tools. No study was excluded based on quality.

Quality assessment for included studies was completed independently by EN \& DM. Any unresolved variances were resolved by a third author (FH). These appraisals were summarised respectively and presented the grading using a range of coding systems. The scores were computed by counting the number of 'Yes' answers. A coding system of $0-10$ was applied to three papers; $8-10$ was considered high quality, 4-7 moderate and below 4 poor. Of the three papers one was considered high and two moderate quality. Two papers were accessed using a coding system of $0-8$ : 7-8 was considered high quality, 6-4 moderate and 3-1 poor. The two papers were each accessed as moderate quality. The remaining paper was accessed using coding system of $1-11 ; 8-11$ was considered high quality, 4-7 moderate and below 4 poor. In terms of quality this paper was rated as high quality (see Table 3).

\section{Data extraction}

A data extraction form was developed on Microsoft Word to extract key data from the included studies. Data extracted included author, year, and aim of the study, geographical location, participants, method, data analysis and priorities identified. Three reviewers (EN, $\mathrm{DM}$ and $\mathrm{OB}$ ) independently extracted data from the final ten papers using the data extraction form and any disagreements were resolved through discussion. A fourth reviewer $(\mathrm{FH})$ was consulted if an agreement could not be reached.

\section{Data synthesis}

Categorical data including year, country, participants, and method were extracted and analysed in Microsoft Excel. Qualitative data underwent a thematic synthesis [37] to integrate the findings of multiple studies and identify which priorities were the most common across the ten included papers and this allowed for the development of higher order themes. Synthesis included line by line coding of the findings of the primary studies, and the categorisation of codes into broad groups of research priorities followed by descriptive themes $[37,46]$. The final stage in the analysis was the development of broad analytical themes.

\section{Results \\ Overview}

The data extracted from the ten included studies $[15,21$, 43-50] are presented in Appendix. The largest group to shape the research priorities were academic, commissioners and healthcare professionals (HCPs) and these were included in eight of the ten studies [15, 21, 43-45, 47, 49, 50]. Families and carers were the second largest group to contribute to the data and were included in two studies [15, 47] . Patients were the sole contributor in one study [48] and contributed as part of a group of patients and families in two other studies [21, 43]. However, these were the only studies in which patients shaped the research priorities. Six of the studies included researchers $[15,43-45,49,50]$, two included researcher/clinicians [43, 50], one included members of the public [15] and two included palliative care volunteers [15, 43]. Details on the sample sizes for each participant group can be found in Appendix.

One study included a search of the international literature and as a result the data was not exclusive to one jurisdiction [46]. The geographical location of the studies was diverse. Three of studies were based in the United Kingdom [44, 47, 48], while one was conducted in both the United Kingdom and Ireland [20]. Each of the remaining five studies geographical location were conducted in New Zealand [21], United States [49], Canada [43], Australia [45] and Africa [50] respectively.

Consensus methodologies were the most commonly used method of developing research priorities. However, there was little consistency in how consensus was gained across the studies as methods were operationalised in different ways. For instance, two studies [21, 45] utilised the Delphi technique while others used workshops [15, 47, 49], a nominal group technique $[44,50]$ or a mixed methods approach involving literature review interviews and online surveys [43] respectively. One study used a systematic review methodology alongside an innovative analytical approach to synthesise evidence from review articles or consensus reports to develop a list of research priorities [46]. One study used a questionnaire as the only method for developing the priorities [48] while others incorporated surveys as one phase of a single priority-setting exercise [15].

\section{Descriptive themes and priority areas}

Following the thematic synthesis [37], the data from the studies were organised into seven descriptive themes, which are described in more detail below. 
Table 3 Quality Appraisal

\begin{tabular}{|c|c|c|c|c|c|c|c|c|c|c|c|c|}
\hline & Q1 & Q2 & Q3 & Q4 & Q5 & Q6 & Q7 & Q8 & Q9 & Q10 & Q11 & Grade \\
\hline \multicolumn{13}{|l|}{ JBI Qualitative } \\
\hline Diffin et al & Y & Y & Y & Y & Y & Y & N/A & Y & U & Y & - & $8 / 10$ \\
\hline Pillemer et al & N/A & Y & Y & Y & Y & U & N/A & Y & N/A/ & Y & - & $6 / 10$ \\
\hline Powel et al. & Y & Y & Y & Y & Y & Y & $\mathrm{N} / \mathrm{A} /$ & Y & N/A/ & Y & - & $8 / 10$ \\
\hline JLA PSP & Y & Y & N/A & N/A & N/A & $N / A$ & Y & Y & - & - & - & $4 / 8$ \\
\hline \multicolumn{13}{|c|}{ JBI Systematic review } \\
\hline Riffin et al. & Y & Y & Y & Y & U & U & Y & Y & U & Y & Y & $8 / 11$ \\
\hline \multicolumn{13}{|c|}{$\mathrm{JBI}$ Cross sectional } \\
\hline Perkins et al & Y & Y & N/A & Y & U & $U$ & U & Y & - & - & - & $4 / 8$ \\
\hline \multicolumn{13}{|l|}{ Key } \\
\hline & \multicolumn{4}{|c|}{ JBI Qualitative Checklist } & \multicolumn{4}{|c|}{ JBI Systematic review } & \multicolumn{4}{|c|}{ JBI Cross sectional } \\
\hline Q1 & \multicolumn{4}{|c|}{$\begin{array}{l}\text { Is there congruity between the stated philosophical } \\
\text { perspective and the research methodology? }\end{array}$} & \multicolumn{4}{|c|}{$\begin{array}{l}\text { Is the review question clearly and } \\
\text { explicitly stated? }\end{array}$} & \multicolumn{4}{|c|}{$\begin{array}{l}\text { Were the criteria for inclusion in the } \\
\text { sample clearly defined? }\end{array}$} \\
\hline Q2 & \multicolumn{4}{|c|}{$\begin{array}{l}\text { Is there congruity between the research } \\
\text { methodology and the research question or } \\
\text { objectives? }\end{array}$} & \multicolumn{4}{|c|}{$\begin{array}{l}\text { Were the inclusion criteria appropriate } \\
\text { for the review question? }\end{array}$} & \multicolumn{4}{|c|}{$\begin{array}{l}\text { Were the study subjects and the } \\
\text { setting described in detail? }\end{array}$} \\
\hline Q3 & \multicolumn{4}{|c|}{$\begin{array}{l}\text { Is there congruity between the research } \\
\text { methodology and the methods used to collect data? }\end{array}$} & \multicolumn{4}{|c|}{ Was the search strategy appropriate? } & \multicolumn{4}{|c|}{$\begin{array}{l}\text { Was the exposure measured in a valid } \\
\text { and reliable way? }\end{array}$} \\
\hline Q4 & \multicolumn{4}{|c|}{$\begin{array}{l}\text { Is there congruity between the research } \\
\text { methodology and the representation and analysis of } \\
\text { data? }\end{array}$} & \multicolumn{4}{|c|}{$\begin{array}{l}\text { Were the sources and resources used } \\
\text { to search for studies adequate? }\end{array}$} & \multicolumn{4}{|c|}{$\begin{array}{l}\text { Were objective, standard criteria used } \\
\text { for measurement of the condition? }\end{array}$} \\
\hline Q5 & \multicolumn{4}{|c|}{$\begin{array}{l}\text { Is there congruity between the research } \\
\text { methodology and the interpretation of results? }\end{array}$} & \multicolumn{4}{|c|}{$\begin{array}{l}\text { Were the criteria for appraising } \\
\text { studies appropriate? }\end{array}$} & \multicolumn{4}{|c|}{ Were confounding factors identified? } \\
\hline Q6 & \multicolumn{4}{|c|}{$\begin{array}{l}\text { Is there a statement locating the researcher culturally } \\
\text { or theoretically? }\end{array}$} & \multicolumn{4}{|c|}{$\begin{array}{l}\text { Was critical appraisal conducted by } \\
\text { two or more reviewers } \\
\text { independently? }\end{array}$} & \multicolumn{4}{|c|}{$\begin{array}{l}\text { Were strategies to deal with } \\
\text { confounding factors stated? }\end{array}$} \\
\hline Q7 & \multicolumn{4}{|c|}{$\begin{array}{l}\text { Is the influence of the researcher on the research, } \\
\text { and vice- versa, addressed? }\end{array}$} & \multicolumn{4}{|c|}{$\begin{array}{l}\text { Were there methods to minimize } \\
\text { errors in data extraction? }\end{array}$} & \multicolumn{4}{|c|}{$\begin{array}{l}\text { Were the outcomes measured in a } \\
\text { valid and reliable way? }\end{array}$} \\
\hline Q8 & \multicolumn{4}{|c|}{$\begin{array}{l}\text { Are participants, and their voices, adequately } \\
\text { represented? }\end{array}$} & \multicolumn{4}{|c|}{$\begin{array}{l}\text { Were the methods used to combine } \\
\text { studies appropriate? }\end{array}$} & \multicolumn{4}{|c|}{$\begin{array}{l}\text { Was appropriate statistical analysis } \\
\text { used? }\end{array}$} \\
\hline Q9 & $\begin{array}{l}\text { Is the } \\
\text { for re } \\
\text { appre }\end{array}$ & $\begin{array}{l}\text { ch eth } \\
\text { udies, } \\
\text { an ap }\end{array}$ & $\begin{array}{l}\text { ording } \\
\text { here e } \\
\text { e body }\end{array}$ & $\begin{array}{l}\text { ent criteria or, } \\
\text { of ethical }\end{array}$ & $\begin{array}{l}\text { Was } \\
\text { asses }\end{array}$ & likelihc & of publi & ion bias & & & & \\
\hline Q10 & $\begin{array}{l}\text { Do th } \\
\text { from }\end{array}$ & $\begin{array}{l}\text { usion } \\
\text { lysis, }\end{array}$ & $\begin{array}{l}n \text { the } r \\
\text { etation, }\end{array}$ & $\begin{array}{l}\text { report flow } \\
\text { data? }\end{array}$ & $\begin{array}{l}\text { Were } \\
\text { and/c } \\
\text { repor }\end{array}$ & $\begin{array}{l}\text { comme } \\
\text { oractice } \\
\text { data? }\end{array}$ & $\begin{array}{l}\text { ons for } \\
\text { orted } k\end{array}$ & & & & & \\
\hline Q11 & & & & & $\begin{array}{l}\text { Were } \\
\text { resea }\end{array}$ & $\begin{array}{l}\text { e speci } \\
\text { ippro }\end{array}$ & $\begin{array}{l}\text { directives } \\
\text { te? }\end{array}$ & r new & & & & \\
\hline
\end{tabular}

\section{Service Models}

This theme focused centrally on the provision of out of hours $(\mathrm{OOH})$ care and home care services across all disease groups [43, 44]. Understanding community care provision, resources, and models and barriers to 24-h care underpinned this theme $[15,21,43-45,47-49]$, with a particular focus on explicating the benefits of home care, understanding and meeting patients' needs, and mechanisms to maintaining independence and enabling patients to remain at home. There is need for better understanding and implementation of a model of care which identifies and delivers the palliative care needs of non-cancer patients in the community [44] and other non-hospital settings (such as primary care or nursing homes) [49]. Researchers called for a systemslevel approach to "develop innovative models for delivering palliative care to community-dwelling patients" [49]. Research evidence is also needed to facilitate the transformation of care from the existing medical model to a person-centred public health approach which uses an organised community effort to provide compassionate care and support for people with life-limiting conditions 
and their families (compassionate community model of care) [43]. More generally, the efficacy of different models in terms of outcomes and cost-effectiveness was also recognised as an important area for research [43].

\section{Continuity of Care}

This theme relates to research that recognises the interdisciplinary nature of palliative care delivery with a view to facilitating greater continuity across all services related to palliative care, to decrease the number of HCPs that patients come into contact with while in receipt of palliative care, as well as exploring how patients transition between services. Specific topics for research included examining the impact of a "designated case coordinator" [15] or exploring how to implement "effective partnering with other providers and specialists in the care of palliative patients" [21]. Improved communication between primary care and hospital was also recognised as a priority for future research that may support greater continuity of care.

\section{Training and Education}

The training and development of non-palliative care specialists was cited as a critical area for research with primary care providers as the main group of HCPs that should be targeted for further training in palliative care, as well as non-hospital based providers $[15,21,43,46,47,49,50]$. Research evidence is also needed to inform content and implementation of training programs for health care professionals on early integration of palliative care [43]. Specifically, future research needs to identify the training needs of primary care providers e.g., "investigate the support and education needs of general practices for provision of palliative care in primary health" [21] and assess "the impact of these programs on both provider practice and patient outcomes" [49]. Additional training for hospice staff and palliative care specialists was also viewed as important with a focus on identifying critical areas for further training, exploring and improving practices regarding palliative care for dementia, and how to engage staff in further training. Moreover, testing and developing training and education programmes for non-professionals such as families and carers was also a priority.

\section{Inequality of Access}

This is a broad theme that incorporates issues pertaining to inequality of access to palliative care services due to diagnosis and a lack of knowledge around disease trajectories for "patients with conditions other than cancer" [49]. Moreover, the paucity of evidence around the cultural and social factors that influence access to palliative care was also highlighted in many of the studies with respect to a "need for equal access to care across different diagnosis groups, socio-economic status and geographical location" [47]. There is need for research to inform interventions to promote equitable access to quality palliative and end-of-life care tailored to meet patient's unique needs especially among hard to reach [43], indigenous [45] and other marginalised groups (such as non-cancer patients) [44].

\section{Communication}

This theme encompasses all aspects of communication in palliative care; there is a need for evidence that will improve communication at every level (e.g. "patient--family or patient-provider decision-making and communication") $[43,45,46]$. This includes communication between services, across specialities, between services and patients, services and families, and patients and their families/carers to facilitate their understanding of transition from active treatment to palliative care $[15,43,45-$ 49]. There is further need to investigate ways by which accurate information about patient's prognosis can be best communicated to them and when [45]. For example, "Helping doctors to hear and understand what patients are saying" [48] as well as establishing "better ways to make sure there is good communication between doctors working in different places" [48] were cited as two key areas where communication can be improved.

\section{Patient Preference and Experience}

This theme incorporates priorities related to specific patient needs and outcomes around the treatment of symptoms (both physiological and psychological) that hinder their ability to live well and with autonomy. Patients are keen to be independent for as long as possible and little is known about their lived experiences of palliative care and "the sense of loss for patients in not being able to participate in activities and hobbies they have previously enjoyed" [21]. Future research should aim to find an appropriate balance between HCP involvement and patients' needs and goals as well the "management of both the patient and carers, and HCPs expectations in relation to their involvement in various aspects of care" [47]. The theme also focuses on goal setting for individual patients so that palliative care outcomes are targeted to their own needs and that research should emphasize "care outcomes and the impact of palliative care as perceived by patients" (48)p39. Research is further needed to inform how the quality of care can be optimised by identifying better ways of managing patient's pain and symptom and reduce the toxic impact of experimental cancer treatments [43].

\section{Recognising the needs and importance of Family Carers}

This theme outlines the necessity for research that provides a greater understanding of the "needs of 
families, caregivers" $[15,50]$ of palliative care [43, 44]. Given the holistic nature of palliative care, research should be wary of isolating patient experiences from those of families/carers and cognisant of the system of support provided to patients by families/carers and the knowledge of the patient they bring to research. Research to promote a better understanding of effective strategies to improve patient and families' involvement in decision-making regarding end-of-life care for the patient and bereavement support for family, was further highlighted as a priority [45]. Finally, establishing "the education/training support needs of carers" [47] was highlighted as a key area of research for this population, in particular with regards to the care they provide at home, for example, "find out what it is like for family member/caregivers to have responsibility for monitoring patient changes and adjusting medications in the home" [21].

\section{Analytical themes}

The seven themes that emerged from the thematic synthesis were closely aligned to the data extracted from the ten included studies. However, it was important to further interpret this data in order to generate a higherorder explanation for the findings. The Donabedian Framework [36] is a model of assessing quality of care and provides a useful mechanism for displaying and analysing this data. This framework will help to provide a standardised model to summarise the research priority results according to quality indicators and identify gaps in the evidence.

The seven descriptive themes are reflective of and mapped onto the three interrelated categories contained within the Donabedian framework, where each category influences the one that succeeds it. Structure refers to the attributes of the settings in which palliative care is delivered. Process involves the activities, from both professionals and patients, that are carried out in giving and receiving care. Outcomes denote the impact of the care on patients and families [51]. Three of the themes
(Service Models, Continuity of Care, Training and Education) are centred on structure and the physical and organisational features of palliative care service provision. Inequality of Access and Communication are elements of the process of care delivered to the patients While Patient Preference and Experience and Recognising the needs and importance of Family Carers are related to the outcomes of care for these populations (see Fig. 2).

\section{Contribution of the included studies to the final themes}

The relative contributions of each of the ten papers to the final themes was examined and the data is displayed in Table 4. Each of the ten studies contributed at least three of descriptive themes and only one study [50] did not contribute to all three analytical themes (as outlined in the Donabedian Framework). Two of the studies $[15,49]$ contributed to all seven descriptive themes.

\section{Discussion}

\section{Main findings of the review}

Seven priority areas were identified from the ten papers included in the systematic review; Service Models, Continuity of Care; Training and Education; Inequality of Access; Communication; Patient Preference and Experience; and Recognising the needs and importance of Family Carers. The themes were mapped to the Donabedian Framework [36], which highlighted that the priorities were associated with the setting, structure variables and the effects on patient outcomes. Despite research emphasising the inclusion of patients and caregivers in research, only five studies $[15,21,43,44,48]$ included the patient and/or caregiver. The need to place the patient at the centre of this process in line with policy is advocated in many countries. This review also analysed the methods used for priority setting, indicating varied approaches were adopted. The majority were based upon consensus methodology however, the operationalisation of consensus and transparency of the process was lacking. This confirms previous work by Viergever and colleagues [28] which suggests there is no gold standard for setting research priorities emphasising the need to
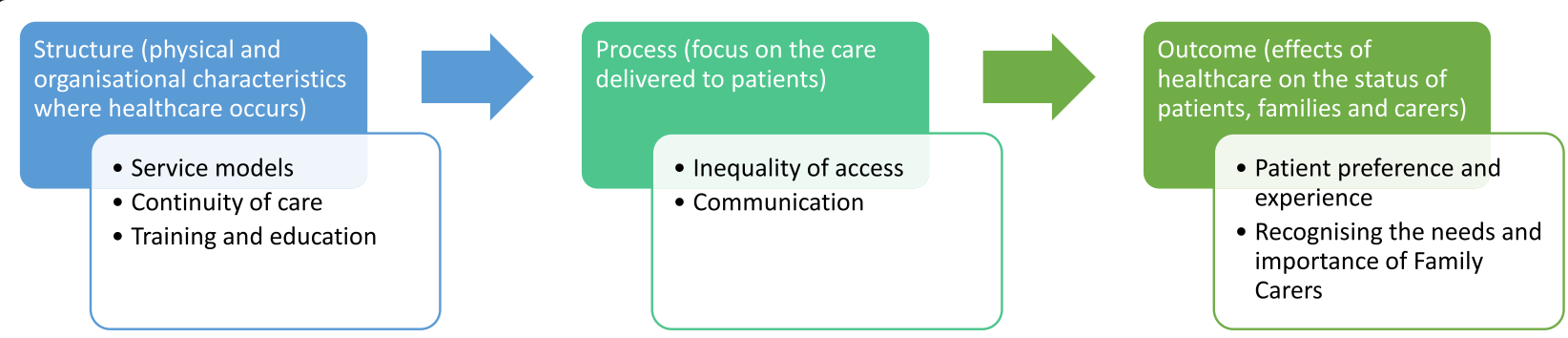

Fig. 2 Analytical Themes incorporated into the Donabedian Framework (1966) for quality of care 
Table 4 Representation of the seven descriptive themes in the included studies mapped to the Donabedian framework

\begin{tabular}{|c|c|c|c|c|c|c|c|c|c|c|c|}
\hline \multicolumn{2}{|c|}{ Donabedian framework } & \multirow{2}{*}{$\begin{array}{l}\text { De } \\
\text { Vries } \\
\text { et al. } \\
2016 \\
X\end{array}$} & \multirow{2}{*}{$\begin{array}{l}\text { Diffin } \\
\text { et al. } \\
2017 \\
X\end{array}$} & \multirow{2}{*}{$\begin{array}{l}\text { Pan- } \\
\text { Canadian } \\
\text { Framework } \\
2017 \\
\text { X }\end{array}$} & \multirow{2}{*}{$\begin{array}{l}\text { PeoLPSP } \\
\text { et al. } \\
2015 \\
x\end{array}$} & \multirow{2}{*}{$\begin{array}{l}\text { Perkins } \\
\text { et al. } \\
2008 \\
X\end{array}$} & \multirow{2}{*}{$\begin{array}{l}\text { Pillemer } \\
\text { et al. } \\
2015 \\
X\end{array}$} & \multirow[t]{2}{*}{$\begin{array}{l}\text { Powell } \\
\text { et al. } \\
2014\end{array}$} & \multirow{2}{*}{$\begin{array}{l}\text { Riffin } \\
\text { et al. } \\
2015 \\
\end{array}$} & \multirow{2}{*}{$\begin{array}{l}\text { Shipman } \\
\text { et al. } \\
2008 \\
\text { X }\end{array}$} & \multirow{2}{*}{$\begin{array}{l}\text { Sullivan } \\
\text { et al. } \\
2018 \\
X\end{array}$} \\
\hline Structure & Service Models & & & & & & & & & & \\
\hline & Continuity of Care & $x$ & $x$ & & $x$ & & $x$ & & $x$ & & \\
\hline & Training and Education & $x$ & $x$ & $x$ & $x$ & & $x$ & $x$ & $x$ & & \\
\hline \multirow[t]{2}{*}{ Process } & Inequality of Access & & $x$ & $x$ & $x$ & & $x$ & & $x$ & $x$ & $x$ \\
\hline & Communication & & $x$ & $x$ & $x$ & $x$ & $x$ & & $x$ & & $x$ \\
\hline \multirow[t]{2}{*}{ Outcomes } & Patient Preference and Experience & $x$ & & $x$ & $x$ & $x$ & $x$ & $x$ & $x$ & & $x$ \\
\hline & $\begin{array}{l}\text { Recognising the needs and } \\
\text { importance of Family Carers }\end{array}$ & $x$ & & $x$ & $x$ & & $x$ & $x$ & & $x$ & $x$ \\
\hline
\end{tabular}

improve the rigorous and transparent reporting of methods.

\section{What is already known and what does this review add} Internationally there is a paucity of research considering the priorities for palliative care research originating from Western countries; only ten papers were identified that contribute to priority setting relevant across palliative care provision. While a proportion of the literature in this area focuses on palliative care provision for individual disease-groups and conditions, it is important to recognise the opportunities for shared learning and commonalities across all populations. This review is the first to synthesize international research priorities for palliative care that have been obtained from empirical research and that are not disease or population specific, onto a tangible framework within the broader healthcare context. The Donabedian framework, has been successfully applied across healthcare settings and contexts as a means of evaluating quality, and within the palliative care context, for example, as a systematic review framework [52], and as a proposed framework for intervention and evaluation studies $[53,54]$. The utilisation of this framework transformed the thematic synthesis into higher order analytical themes that can be taken forward strategically to improve palliative care research. To the authors' knowledge, this is the first systematic review to apply the Donabedian's framework to mapping palliative care research priorities.

Palliative care is a field of healthcare in receipt of a historically small proportion of research funding [8, 9], therefore, it is essential to ensure that research value is maximised. In 2009, Chalmers and Glasziou [55] estimated that $85 \%$ of all health research is being avoidably "wasted". Whilst it can be argued that progress has been made, over the last decade, Glasziou and Chalmers more recently [56] claimed that health service research still has a have a long way to go, with continued concerns over research design, conduct and reporting. When analysing the priority areas identified, it is important to be cognisant of these concerns and ensure that the palliative care research projects to address these priorities are of sufficient quality and rigour to address and mediate such concerns.

One of the central issues about priority setting is addressing the question around who should be involved in the process, and how can this be enabled. Findings from this review suggests the care providers are the dominant perspective, with the patient's largely missing. This may explain why priorities are largely service orientated with notable gaps in the priorities relating to quality of life and symptom management. Given that patient perspectives routinely differ from those of other stakeholders [57], the need to elevate their voice to enhance the legitimacy in the identification of priorities is required. Doing so will help to ensure that future research addresses questions of relevance, helping decision-makers and service providers to be better equipped to design and deliver health services to meet patient/service user need [58]. Whilst researchers have acknowledged the need for greater patient involvement in research and planning [59], their inclusion is questioned by an array of ethical, practical and medical challenges [60], further complicated by researcher concerns about their roles and values [61, 62]. Nevertheless, the need to find new robust processes to support meaningful contribution of patients to enable inclusion in strategic directions in palliative care is required to ensure the inequality [2] is reduced and the research is not considered wasteful [35].

A second issue relates to how information is collected. Variations of methodological approaches exist, with little agreement on what constitutes reporting standards, guidelines or best practice [28,63]. Findings in this study demonstrate great variation in the approaches used to organise research priority-setting exercises. Whilst 
consensus was the most common means to generate research priorities in the ten included studies, a myriad of approaches were used such as the Delphi technique, nominal group and consensus workshops, as well as a range of analysis techniques, for instance, ranking, statistical analyses and an immersion crystallisation framework. Within the ten studies, inconsistent reporting of priority development was noted and was a barrier when synthesizing the evidence across studies. Such variation and lack of consistency make it difficult to judge the validity and transferability of the priorities reported, creating a significant barrier to aggregating and reporting comparative findings across international contexts [63]. Given that credibility of consensus findings is influenced by the rigour application of the approach, we need to ensure the reporting and guidance by acceptable standards in palliative care is advocated [2, 64]. Moreover the application of the checklist to help standardise research priority setting in health could be used to inform priority setting exercises going forward [28].

A third issue relates to the context and landscape in which the priority setting is undertaken. In this review, the majority of priority setting exercises were conducted in countries with an preliminary (i.e., New Zealand) or advanced (i.e., UK, Ireland, U.S.A, Canada and Australia) level of palliative care programmes and integration into mainstream health services [65]. A gap in the knowledge of priorities representing those in lower and middleincome countries (LMIC) exists, echoing previous reviews of international palliative care research $[66,67]$. Whilst there is evidence in this review of engagement, with researchers from high-income regions collaborating and undertaking research in Africa (Powell et al., 2014), a number of researchers [31, 67] suggest this raises multi-faceted challenges including the risk of imposing western norms in differing cultural contexts [68]. Therefore, the application of western research priority findings is limited, if not adapted to the specific economic, cultural and specific health care context and constraints of lower- and middle-income countries. Zaman et al. [31] suggests the need for LMIC to initially develop culturally and locally appropriate research, and then move towards international comparative research.

\section{Strengths and limitations}

This review represents an initial step towards mapping international palliative care research which may help to inform policy and funding bodies on future action. However, it has several limitations for example, the search was limited to English language articles, which limits the generalizability of the findings. Moreover, it is recognised that this review excluded, disease specific empirical studies such as dementia and for specific populations such as intellectual disability however, the inclusion of such evidence would have resulted in greater heterogeneity between studies and limited the ability to synthesise the findings. The search was also limited that the exclusion of patient and public involvement which may have captured more caregiver and patient perspectives. Additionally, some of the studies lacked detailed information on the methodological analysis and procedures employed, questioning the rigour and validity.

\section{Implications for policy, practice, and research}

This systematic review has called attention to the need for more end users in research priority setting exercises, therefore, researchers and funding bodies should develop new strategies to ensure meaningful participation of palliative care patients and families, building in structures and processes to account for the vulnerability often present within this population. Findings provide an initial blueprint for palliative care research funders and policymakers to contribute to the future research agenda for palliative care from a patient and HCP perspective. Given that funding resources are limited the importance of collaboration and international approaches to palliative care is growing, these findings may help to inform this debate.

Methodologically, a standardised approach and reporting for priority setting is advocated allowing for increased validity and comparability of findings from across palliative care settings. Due to varied methods and analytical techniques, an additional challenge was presented for the authors of this review when trying to compare and weight studies. Future attempts to set research priorities should involve a multi discipinary representation of stakeholders, such inclusion will provide credibility and enhance the feasibility of the developed priorities. Whilst it is outside the remit of this review to specific an appropriate prirotiy setting methodology, the conduct of any such exercises should be governed by methodological guidelines, clear objectives and defined criteria and concepts, for identifying and ranking priorities. Doing so, will aid the transparency of the process and credibility of the results.

\section{Conclusions}

A review of the international palliative care priorities generated a list of common denominators within the palliative care landscape. However, it is unclear if they align with the needs and concerns of the patent and caregiver who are at the centre of palliative care. In addition, the reporting of the priority process was ambiguous which raises questions regarding the credibility of findings. The findings of this study may serve as a template to understand the commonalities of research and enhance dialogue in palliative care research. 


\section{Appendix}

Table 5 Data extraction

\begin{tabular}{lrl}
\hline Authors & Year & Aim of Study \\
\hline $\begin{array}{l}\text { De Vries } \\
\text { et al. }\end{array}$ & $\begin{array}{l}\text { To inform } \\
\text { organizational decision } \\
\text { making and policy } \\
\text { development regarding } \\
\text { future research } \\
\text { priorities for a hospice } \\
\text { service in New Zealand }\end{array}$ \\
& \\
& \\
& \\
& \\
& \\
& \\
& \\
Diffin et al. 2017 & $\begin{array}{l}\text { The aim of this project } \\
\text { was to identify EoL } \\
\text { research priorities } \\
\text { specific to Greater } \\
\text { Manchester via a } \\
\text { consultation process } \\
\text { with both healthcare } \\
\text { professionals (HCPs) } \\
\text { and carers }\end{array}$ \\
&
\end{tabular}

\begin{tabular}{|c|c|c|c|c|}
\hline $\begin{array}{l}\text { Geographical } \\
\text { Location }\end{array}$ & Participants & Methodology & Data Analysis & $\begin{array}{l}\text { Priorities Identified } \\
\left(\text { summary }{ }^{\mathrm{a}}\right)\end{array}$ \\
\hline New Zealand & $\begin{array}{l}\text { Palliative care staff ( } n= \\
10,18 \text {, and } 9 \text { per round } \\
1-3 \text { ) volunteers }(n=10, \\
12,11 \text { per round) } \\
\text { patients and family } \\
\text { members ( } n=6,8 \text { for } \\
\text { round } 1 \text { and } 2) \text {, and } \\
\text { community linked } \\
\text { professionals }(n=3)\end{array}$ & $\begin{array}{l}\text { Modified Delphi } \\
\text { Technique }\end{array}$ & $\begin{array}{l}\text { Descriptive } \\
\text { statistics. For each } \\
\text { question, the } \\
\text { proportion of } \\
\text { scores of four or } \\
\text { more were } \\
\text { calculated and } \\
\text { ranked to } \\
\text { identify the } 48 \\
\text { most preferred } \\
\text { topics }\end{array}$ & $\begin{array}{l}\text { Patients and Families: } \\
\text { - Decision-making } \\
\text { - Bereavement and loss } \\
\text { - Symptom } \\
\text { management } \\
\text { - Recognition of need } \\
\text { and response of } \\
\text { service } \\
\text { Staff and Volunteers: } \\
\text { - Symptom } \\
\text { management } \\
\text { - Aged care } \\
\text { - Education } \\
\text { - Community } \\
\text { - Patient/family } \\
\text { - Bereavement \& } \\
\text { support for young } \\
\text { people }\end{array}$ \\
\hline
\end{tabular}

Greater

Manchester

(United Kingdom of

Great Britain and Northern Ireland)
Healthcare Professionals from Greater Manchester $(n=32) /$ Family carers from greater Manchester $(n=26)$
Initial Scoping followed by consultation through informal workshops and interviews
Data organised under six main topic areas and ranked
Palliative

and end of

life care

Priority

Setting

Partnership
2015 To identify unanswered questions which are most important for people in their last years of life, current and bereaved carers, and health and social care professionals
United 1403 initial survey

Kingdom and Ireland

participants (48\% professional; $35 \%$ bereaved carers; $13 \%$ other; 4\% patients; 3\% volunteers) ${ }^{\mathbf{a}}$ 1331 interim prioritisation survey participants (64\% professional; 22\% bereaved family/carer; 9\% current family /carers; $11 \%$ other; $8 \%$ public; 2\% patient) ${ }^{\text {a }}$

24 workshop participants

a overlap reported in categories as respondents reported as belonging to more than one category current carers; $10 \%$
James Lind Ranking

Alliance

Initial survey

generated 83

Qs. Ranking of

83 priorities.

Workshop (NGT)

ranked top 28

questions to

priorities
Methodology

result in 10

Top 3 priorities for both groups:

1. Access to $24 \mathrm{~h}$ care 2. Planning end-of-life care in advance 3. Staff and carer education

Common themes:

- Need for improved communication between stakeholders

- Need for equal access to care

- Management of both the patient and carers, and HCPs

Top 10 in order of priority:

1. The best ways of providing palliative care outside of working hours.

2. Improving access to palliative care services be improved for everyone regardless of location?

3. Benefits of Advance Care Planning and other approaches. 4. Information and training for carers and families

5. Ensuring staff, including healthcare assistants, are adequately trained. 6. Determining palliative care needs for patients with noncancer diseases 7. Core palliative care services regardless of diagnosis.

8. Benefits of providing care in the patient's home 
Table 5 Data extraction (Continued)

\begin{tabular}{|c|c|c|c|c|c|c|c|}
\hline Authors & Year & Aim of Study & $\begin{array}{l}\text { Geographical } \\
\text { Location }\end{array}$ & Participants & Methodology & Data Analysis & $\begin{array}{l}\text { Priorities Identified } \\
\text { (summary }^{a} \text { ) }\end{array}$ \\
\hline & & & & & & & $\begin{array}{l}\text { 9. Ensuring continuity } \\
\text { for patients at the end } \\
\text { of life. } \\
\text { 10. Assessing and } \\
\text { treating pain and } \\
\text { discomfort in people at } \\
\text { the end of life with } \\
\text { communication and/or } \\
\text { cognitive difficulties. }\end{array}$ \\
\hline $\begin{array}{l}\text { Pan- } \\
\text { Canadian } \\
\text { Framework } \\
\text { for } \\
\text { Palliative } \\
\text { and End - } \\
\text { of-Life Care } \\
\text { Research }\end{array}$ & 2017 & $\begin{array}{l}\text { To develop a research } \\
\text { framework for palliative } \\
\text { and end-of-life care }\end{array}$ & Canada & $\begin{array}{l}36 \text { Interviews with } \\
\text { individuals drawn from } \\
\text { a number of } \\
\text { stakeholder groups } \\
\text { (patients, caregivers, } \\
\text { health care } \\
\text { practitioners, health } \\
\text { care administrators, } \\
\text { opinion leaders and } \\
\text { others with an interest } \\
\text { in palliative and eol } \\
\text { issues. } \\
172 \text { completed surveys } \\
\text { (51 patients/caregivers; } \\
41 \text { practitioners; } 62 \\
\text { Researcher/Clinician } \\
\text { Researcher; } 13 \text { decision } \\
\text { makers; } 5 \text { volunteers) }\end{array}$ & $\begin{array}{l}\text { Literature } \\
\text { review (2005- } \\
\text { 2013), } \\
\text { interviews (face- } \\
\text { to face and by } \\
\text { telephone and } \\
\text { online survey }\end{array}$ & $\begin{array}{l}\text { Thematic } \\
\text { grouping }\end{array}$ & $\begin{array}{l}\text { Priority research areas } \\
\text { identified under three } \\
\text { broad themes and } \\
\text { eight sub-themes: } \\
\text { 1. Transforming model } \\
\text { of care } \\
\text { a. Engaging } \\
\text { communities using a } \\
\text { public health approach } \\
\text { b. Early and integrated } \\
\text { palliative care } \\
\text { c. Access to quality } \\
\text { palliative and end-of- } \\
\text { life care } \\
\text { 2. Patient and family } \\
\text { centeredness } \\
\text { a. Pain and symptom } \\
\text { management } \\
\text { b. Optimising quality of } \\
\text { care } \\
\text { c. Person-reported } \\
\text { outcomes } \\
\text { 3. Ensuring equity } \\
\text { a. Addressing the } \\
\text { needs of special } \\
\text { populations } \\
\text { b. Addressing health } \\
\text { disparities }\end{array}$ \\
\hline $\begin{array}{l}\text { Perkins } \\
\text { et al. }\end{array}$ & 2008 & $\begin{array}{l}\text { Assess patients research } \\
\text { priorities for palliative } \\
\text { care }\end{array}$ & $\begin{array}{l}\text { East Anglia } \\
\text { (United } \\
\text { Kingdom of } \\
\text { Great Britain } \\
\text { and Northern } \\
\text { Ireland) }\end{array}$ & Patients $(n=112)$ & Questionnaire & Statistical Analysis & $\begin{array}{l}\text { Questions } \\
\text { 1. Emergency: } \\
\text { 2. Pain Control: } \\
\text { 3. Helping doctors to } \\
\text { hear and understand } \\
\text { what patients are } \\
\text { saying } \\
\text { Thematic areas ranking: } \\
\text { 1. Talking with patients } \\
\text { 2. Medication } \\
\text { 3. Symptoms } \\
\text { 4. Help for patients/ } \\
\text { families }\end{array}$ \\
\hline $\begin{array}{l}\text { Pillemer } \\
\text { et al. }\end{array}$ & 2015 & $\begin{array}{l}\text { To identify knowledge } \\
\text { gaps and types of } \\
\text { studies that should be } \\
\text { conducted to improve } \\
\text { providers' ability to } \\
\text { deliver palliative care } \\
\text { most effectively. }\end{array}$ & $\begin{array}{l}\text { New York, } \\
\text { United States } \\
\text { of America }\end{array}$ & $\begin{array}{l}\text { Researchers }(n=18) \\
\text { Practitioners }(n=65)\end{array}$ & $\begin{array}{l}\text { Research- } \\
\text { Practice } \\
\text { Consensus } \\
\text { Workshop }\end{array}$ & $\begin{array}{l}\text { Ranking and } \\
\text { consensus }\end{array}$ & $\begin{array}{l}\text { - Research to improve } \\
\text { individual-level pallia- } \\
\text { tive care practice } \\
\text { - Research is needed } \\
\text { on the physiology of } \\
\text { the end of life, } \\
\text { including nutrition, } \\
\text { hydration, and } \\
\text { oxygen, and on } \\
\text { nonpharmacological } \\
\text { approaches, including } \\
\text { complementary and } \\
\text { alternative therapies. } \\
\text { - Research to improve } \\
\text { system-level palliative } \\
\text { care practice and }\end{array}$ \\
\hline
\end{tabular}


Table 5 Data extraction (Continued)

\begin{tabular}{|c|c|c|c|c|c|c|c|}
\hline Authors & Year & Aim of Study & $\begin{array}{l}\text { Geographical } \\
\text { Location }\end{array}$ & Participants & Methodology & Data Analysis & $\begin{array}{l}\text { Priorities Identified } \\
(\text { summary })\end{array}$ \\
\hline & & & & & & & $\begin{array}{l}\text { capacity } \\
\text { - Research on societal } \\
\text { context for palliative } \\
\text { care in the United } \\
\text { States }\end{array}$ \\
\hline $\begin{array}{l}\text { Powell } \\
\text { et al. }\end{array}$ & 2014 & $\begin{array}{l}\text { To develop a prioritized } \\
\text { research agenda for } \\
\text { palliative care in } \\
\text { Africa. }\end{array}$ & Africa & $\begin{array}{l}\text { Palliative care } \\
\text { professionals and } \\
\text { Researchers } \\
\text { Phase 1: }(n=49) \\
\text { Phase 2: }(n=14)\end{array}$ & $\begin{array}{l}\text { Phase 1: } \\
\text { Consultative } \\
\text { workshop } \\
\text { Phase 2: } \\
\text { Prioritization } \\
\text { using a } \\
\text { consensus } \\
\text { development } \\
\text { process. }\end{array}$ & $\begin{array}{l}\text { Descriptive } \\
\text { analysis }\end{array}$ & $\begin{array}{l}\text { Three broad thematic } \\
\text { areas were identified: } \\
\text { - Patient, family, and } \\
\text { volunteers } \\
\text { - Health providers } \\
\text { - Health systems }\end{array}$ \\
\hline Riffin et al. & 2015 & $\begin{array}{l}\text { To identify important } \\
\text { directions for future } \\
\text { research and inform } \\
\text { the development of } \\
\text { effective health policy } \\
\text { and clinical practice in } \\
\text { palliative care. }\end{array}$ & $\begin{array}{l}\text { International } \\
\text { Literature }\end{array}$ & $\mathrm{n} / \mathrm{a}$ & $\begin{array}{l}\text { Innovative } \\
\text { Analytic } \\
\text { Approach } \\
\text { (Systematic } \\
\text { Review } \\
\text { technique) }\end{array}$ & $\begin{array}{l}\text { Immersion--- } \\
\text { crystallization } \\
\text { framework }\end{array}$ & $\begin{array}{l}\text { The identified research } \\
\text { recommendations fell } \\
\text { into } 2 \text { distinct, broad } \\
\text { themes: } \\
\text { - ways in which } \\
\text { research } \\
\text { methodological } \\
\text { approaches should be } \\
\text { improved } \\
\text { - specific topic areas in } \\
\text { need of future study }\end{array}$ \\
\hline $\begin{array}{l}\text { Shipman } \\
\text { et al. }\end{array}$ & 2008 & $\begin{array}{l}\text { To investigate what } \\
\text { was understood by } \\
\text { generalist end of life } \\
\text { care and the current } \\
\text { concerns and } \\
\text { preferences for service } \\
\text { research and } \\
\text { development from the } \\
\text { perspectives of } \\
\text { clinicians, user groups, } \\
\text { commissioners, } \\
\text { academics and policy } \\
\text { makers. }\end{array}$ & $\begin{array}{l}\text { United } \\
\text { Kingdom - } \\
\text { London, East } \\
\text { of England, } \\
\text { Warwickshire } \\
\text { and Scotland }\end{array}$ & $\begin{array}{l}210 \text { participants } \\
\text { including: health and } \\
\text { social care practitioners; } \\
\text { service commissioners; } \\
\text { policy makers; } \\
\text { academics; user and } \\
\text { voluntary groups }\end{array}$ & $\begin{array}{l}\text { National } \\
\text { consultation } \\
\text { and } \\
\text { prioritisation } \\
\text { exercise using a } \\
\text { modified form } \\
\text { of nominal } \\
\text { group } \\
\text { technique. } \\
\text { Semi-structured } \\
\text { questionnaires } \\
\text { administered by } \\
\text { email and } \\
\text { telephone/ } \\
\text { face = to-face } \\
\text { interviews }\end{array}$ & Thematic analysis & $\begin{array}{l}\text { Research priorities } \\
\text { identified in generalist } \\
\text { end of life care } \\
\text { included: } \\
\text { - The need to improve } \\
\text { service provision, } \\
\text { including out of hours } \\
\text { care } \\
\text { - Identification of a } \\
\text { model of care to } \\
\text { address the } \\
\text { supportive and } \\
\text { palliative care needs } \\
\text { of non-cancer patients } \\
\text { in the community } \\
\text { - Place of care and } \\
\text { death and the } \\
\text { associated costs and } \\
\text { resources to be } \\
\text { supported within } \\
\text { national policies on } \\
\text { care delivery } \\
\text { - Understanding of } \\
\text { patients and carers' } \\
\text { experiences }\end{array}$ \\
\hline $\begin{array}{l}\text { Sullivan } \\
\text { et al. }\end{array}$ & 2018 & $\begin{array}{l}\text { To gain a consensus on } \\
\text { the research priorities } \\
\text { of palliative care } \\
\text { clinicians and } \\
\text { researchers with a view } \\
\text { to establish a prioritised } \\
\text { research agenda for } \\
\text { adult palliative care in } \\
\text { Australia }\end{array}$ & Australia & $\begin{array}{l}25,14 \text { and } 13 \text { panelists } \\
\text { (experts in palliative } \\
\text { care research and/or } \\
\text { practice in Australia) in } \\
\text { rounds } 1,2 \text { and } 3 \\
\text { respectively. }\end{array}$ & $\begin{array}{l}\text { A modified } \\
\text { three round } \\
\text { Delphi survey } \\
\text { using } \\
\text { questionnaires } \\
\text { administered } \\
\text { online }\end{array}$ & Statistical analysis. & $\begin{array}{l}\text { Research priorities } \\
\text { which emerged from } \\
\text { the three rounds were } \\
\text { ranked in order to } \\
\text { priority to the top ten } \\
\text { listed as: } \\
\text { - To develop } \\
\text { communication which } \\
\text { facilitates patients' } \\
\text { and families' } \\
\text { understanding of } \\
\text { transition from active } \\
\text { treatment to palliative } \\
\text { care } \\
\text { - To improve the }\end{array}$ \\
\hline
\end{tabular}


Table 5 Data extraction (Continued)

\begin{tabular}{|c|c|c|c|c|}
\hline Authors & Year Aim of Study & $\begin{array}{l}\text { Geographical Participants } \\
\text { Location }\end{array}$ & Methodology Data Analysis & $\begin{array}{l}\text { Priorities Identified } \\
\left(\text { summary }{ }^{\mathrm{a}}\right)\end{array}$ \\
\hline & & & & $\begin{array}{l}\text { communication of } \\
\text { accurate information } \\
\text { about prognosis to } \\
\text { patients when } \\
\text { diagnosed } \\
\text { - To improve palliative } \\
\text { care for indigenous } \\
\text { communities } \\
\text { - To establish palliative } \\
\text { care models for those } \\
\text { who wish to remain } \\
\text { at home but have } \\
\text { significant care needs } \\
\text { outside of care } \\
\text { provided routinely } \\
\text { - routine and formal } \\
\text { identification and } \\
\text { addressing of family } \\
\text { caregivers' support } \\
\text { needs during the } \\
\text { palliative care } \\
\text { trajectory } \\
\text { - to investigate how } \\
\text { the aged care sector } \\
\text { can identify and } \\
\text { provide for the } \\
\text { potentially chronic } \\
\text { end-of-life support to } \\
\text { aged people with } \\
\text { multiple comorbid } \\
\text { conditions but with- } \\
\text { out a clear diagnosis } \\
\text { for palliative } \\
\text { intervention } \\
\text { - to improve patients' } \\
\text { and families' } \\
\text { involvement in } \\
\text { decisions regarding } \\
\text { care in the last week } \\
\text { of life } \\
\text { - to explore cross- } \\
\text { cultural approaches to } \\
\text { terminal illness, death } \\
\text { and dying and how } \\
\text { these can inform pal- } \\
\text { liative care } \\
\text { - to assess the impact } \\
\text { of the legislation on } \\
\text { assisted dying on } \\
\text { family decision- } \\
\text { making and bereave- } \\
\text { ment outcomes } \\
\text { to improve } \\
\text { bereavement care in } \\
\text { rural, remote and } \\
\text { aboriginal populations }\end{array}$ \\
\hline
\end{tabular}




\section{Abbreviations}

CINAHL: Cumulative Index of Nursing and Allied Health Literature; EMBASE: Excerpta Medica database; HCP: Health Care Professionals; JBI: Joanna Briggs Institute; LMIC: Lower and Middle-Income Countries; OOH: Out of Hours (OOH); PRISMA: Preferred Reporting Items for Systematic Reviews and Meta-Analyses; U.S.A: United States of America; UK: United Kingdom

\section{Acknowledgements}

Not Applicable.

\section{Authors' contributions}

All authors contributed to the conception and design of this work and interpretation of data or drafting and revising it critically for intellectual content. Analysis of data was undertaken by FH, DM and EN. All authors read and approved the final manuscript.

\section{Funding}

This research received no specific grant from any funding agency in the public, commercial, or not-for-profit sectors.

\section{Availability of data and materials}

The datasets used and/or analysed during the current study are available from the corresponding author on reasonable request.

\section{Ethics approval and consent to participate}

Not Applicable.

\section{Consent for publication}

Not Applicable.

\section{Competing interests}

The authors declare that they have no competing interests.

\section{Author details}

'Institute of Nursing and Health Research, School of Nursing, Ulster University, Shore Road, Newtownabbey BT37 OQB, Northern Ireland. ${ }^{2}$ UCD School of Nursing, Midwifery and Health Systems, UCD College of Health and Agricultural Sciences, University College Dublin, Belfield, Dublin 4, Ireland. ${ }^{3}$ Academcy of Primary Care, Hull York Medical School, Allam Medical Building, University of Hull, Hull HU6 7RZ, England. ${ }^{4}$ International Observatory on End of Life Care, Lancaster University, LA14YX, Lancaster, UK.

Received: 23 October 2019 Accepted: 17 January 2020

Published online: 03 February 2020

\section{References}

1. World Health Organization. Palliative Care [Internet]. Fact Sheets. 2018 [cited 2018 Sep 27]. Available from: http:/www.who.int/en/news-room/factsheets/detail/palliative-care

2. Knaul FM, Farmer PE, Krakauer EL, De Lima L, Bhadelia A, Jiang Kwete $X$, et al. Alleviating the access abyss in palliative care and pain relief-an imperative of universal health coverage: the Lancet Commission report. Lancet. 2018;391 (10128):1391-454 [cited 2019 may 30] Available from: http://www.ncbi.nlm.nih.gov/pubmed/29032993.

3. Sleeman KE, de Brito M, Etkind S, Nkhoma K, Guo P, Higginson IJ, et al. The escalating global burden of serious health-related suffering: projections to 2060 by world regions, age groups, and health conditions. Lancet Glob Heal. 2019;7(7):e883-92 [cited 2019 Jun 26] Available from: http://www.ncbi. nlm.nih.gov/pubmed/31129125.

4. Powell RA, Mwangi-Powell FN, Radbruch L, Yamey G, Krakauer EL, Spence D, et al. Putting palliative care on the global health agenda. Lancet Oncol. 2015;16(2):131-3 [cited 2018 Nov 29] Available from: http://www.ncbi.nlm. nih.gov/pubmed/25638676.

5. Harding R, Higginson IJ. Inclusion of end-of-life care in the global health agenda. Lancet Glob Heal. 2014;2(7):e375-6 [cited 2018 Nov 30] Available from: http://www.ncbi.nlm.nih.gov/pubmed/25103378.

6. Brennan F. Palliative Care as an International Human Right. J Pain Symptom Manage. 2007;33(5):494-9 [cited 2018 Nov 29] Available from: http://www.ncbi.nlm.nih.gov/pubmed/17482036.
7. Gwyther L, Brennan F, Harding R. Advancing Palliative Care as a Human Right. J Pain Symptom Manage. 2009;38(5):767-74 [cited 2018 Nov 29] Available from: http://www.ncbi.nlm.nih.gov/pubmed/19783399.

8. Mcllfatrick S, DHL M, Hasson F, Payne S. Examining palliative and end of life care research in Ireland within a global context: a systematic mapping review of the evidence. BMC Palliat Care. 2018;17(1):109 [cited 2018 Nov 14] Available from: https://bmcpalliatcare.biomedcentral.com/articles/10.1186/ s12904-018-0364-7.

9. Higginson I. Research challenges in palliative and end of life care. BMJ Support Palliat Care. 2016;6(1):2-4 [cited 2017 Jul 21] Available from: http:// www.ncbi.nlm.nih.gov/pubmed/26893386.

10. Marie Curie. Marie Curie's contribution to palliative and end of life care research funding in the UK [Internet]. 2015 [cited 2018 Feb 15]. Available from: https://www.mariecurie.org.uk/globalassets/media/documents/ research/publications/ncri-analysis-report.pdf

11. McGregor S, Henderson KJ, Kaldor JM, Molyneux S. How are health research priorities set in low and middle income countries? A systematic review of published reports. PLoS One. 2014;9(10):e108787 [cited 2018 Nov 29] . Available from: https://dx.plos.org/10.1371/journal.pone.0108787.

12. World Health Organization. Global Status on noncommunicable diseases [Internet]. 2010 [cited 2018 Nov 30]. Available from: http://www.who.int/ about/licensing/copyright_form/en/index.html

13. Spence M, Spencer R, Diffin J, Mellor P, Grande G. Priority setting for end-oflife care. BMJ Support Palliat Care. 2016;6(3):1-399 [cited 2018 Nov 29] Available from: http://spcare.bmj.com/lookup/doi/10.1136/bmjspcare-2016001204.39.

14. Best S, Tate T, Noble B, Eley J, Black J, Stockton M, et al. The palliative and end of life care priority setting partnership (PEOLCPSP): Determining evidence uncertainties from the perspective of the end user of research. BMJ Support Palliat Care. 2014:4(Suppl 1):A42.1-A42 [cited 2018 Nov 29] Available from: http://spcare.bmj.com/lookup/doi/10.1136/bmjspcare-2014-000654.117.

15. PeolcPSP. Palliative and end of life care Priority Setting Partnership - Final Report [Internet]. 2015. Available from: Palliative and end of life care Priority Setting Partnership.

16. Lechelt LA, Rieger JM, Cowan K, Debenham BJ, Krewski B, Nayar S, et al. Top 10 research priorities in head and neck cancer: results of an Alberta priority setting partnership of patients, caregivers, family members, and clinicians. Head Neck. 2018:40(3):544-54.

17. Fox S, FitzGerald C, Harrison Dening K, Irving K, Kernohan WG, Treloar A, et al. Better palliative care for people with a dementia: summary of interdisciplinary workshop highlighting current gaps and recommendations for future research. BMC Palliat Care. 2018;(1):17, 9 [cited 2018 Nov 29] Available from: http://bmcpalliatcare.biomedcentral.com/articles/10.1186/s12 904-017-0221-0.

18. Tuffrey-Wijne I, Wicki M, Heslop P, McCarron M, Todd S, Oliver D, et al. Developing research priorities for palliative care of people with intellectual disabilities in Europe: a consultation process using nominal group technique. BMC Palliat Care. 2016;15(1):36 [cited 2017 Apr 11] Available from: http:// bmcpalliatcare.biomedcentral.com/articles/10.1186/s12904-016-0108-5.

19. Combs S, Kluger BM, Kutner JS. Research priorities in geriatric palliative care: nonpain symptoms. J Palliat Med. 2013;16(9):1001-7 [cited 2018 Nov 29] Available from: http://www.ncbi.nlm.nih.gov/pubmed/23888305.

20. Quest TE, Asplin BR, Cairns CB, Hwang U, Pines JM. Research priorities for palliative and end-of-life care in the emergency setting. Acad Emerg Med. 2011;18(6):e70-6 [cited 2018 Nov 30] Available from: http://www.ncbi.nlm. nih.gov/pubmed/21676052.

21. de Vries K, Walton J, Nelson K, Knox R. An examination of the research priorities for a hospice service in New Zealand: A Delphi study. Palliat Support Care. 2016;14:232-40 [cited 2018 Jul 2] Available from: http://www. ncbi.nlm.nih.gov/pubmed/26079850.

22. Aldiss S, Fern LA, Phillips B, Gibson F, on behalf of the Teenage and Young Adult Cancer Priority Setting Partnership Steering. Teenage and Young Adult Cancer: Research Priorities. Final Report of the James Lind Alliance Priority Setting Partnership [Internet]. United Kingdom; 2018 [cited 2018 Nov 30]. Available from: http://www.jlanihr.ac.uk/priority-settingpartnerships/teenage-and-young-adult-cancer/downloads/teenage-andyoung-adult-cancer-PSP-final-report.pdf

23. O'Hare AM, Song M-K, Kurella Tamura M, Moss AH. Research Priorities for Palliative Care for Older Adults with Advanced Chronic Kidney Disease. J Palliat Med. 2017:20(5):453-60 [cited 2018 Nov 29] Available from: http:// www.ncbi.nlm.nih.gov/pubmed/28463635. 
24. Lilley EJ, Cooper Z, Schwarze ML, Mosenthal AC. Palliative Care in Surgery. Ann Surg. 2018;267(1):66-72 [cited 2018 Nov 30] Available from: http:// www.ncbi.nlm.nih.gov/pubmed/28471764.

25. HPNA. Hospice and Palliative Nurses Association 2015-2018 Research Agenda. J Hosp Palliat Nurs [Internet]. 2015 Apr [cited 2018 Nov 29];17(2): 119-27. Available from: https://insights.ovid.com/crossref?an=00129191-2 01504000-00009

26. Liossi C, Anderson AK, Howard RF. Development of research priorities in paediatric pain and palliative care. Br J Pain. 2017;11(1):9-15 [cited 2018 Nov 29] Available from: http://www.ncbi.nlm.nih.gov/pubmed/28386399.

27. Selman L, Young T, Vermandere M, Stirling I, Leget C. Research Subgroup of European Association for Palliative Care Spiritual Care Taskforce. Research Priorities in Spiritual Care: An International Survey of Palliative Care Researchers and Clinicians. J Pain Symptom Manage. 2014;48(4):518-31 [cited 2018 Nov 29] Available from: http://www.ncbi.n/m.nih.gov/ pubmed/24680625.

28. Viergever RF, Olifson S, Ghaffar A, Terry RF. A checklist for health research priority setting: nine common themes of good practice. Health Res Pol Syst. 2010:8:36.

29. Tomlinson M, Yasamy MT, Emerson E, Officer A, Richler D, Saxena S. Setting global research priorities for developmental disabilities, including intellectual disabilities and autism. J Intellect Disabil Res. 2014; 58(12):1121-30.

30. Viergever RF. Health research prioritization at WHO An overview of methodology and high level analysis of WHO led health research priority setting exercises [Internet]. 2010 [cited 2019 Jun 21]. Available from: https://www.who.int/rpc/publications/Health_research_ prioritization_at_WHO.pdf

31. Zaman S, Inbadas H, Whitelaw A, Clark D. Common or multiple futures for end of life care around the world? Ideas from the 'waiting room of history.'. Soc Sci Med. 2017;172:72-9 [cited 2019 Jun 21] Available from: http://www. ncbi.nlm.nih.gov/pubmed/27894008.

32. Tallon D, Chard J, Dieppe P. Relation between agendas of the research community and the research consumer. Lancet. 2000;355(9220):2037-40 [cited 2018 Nov 29] Available from: http://www.ncbi.nlm.nih.gov/pubmed/1 0885355.

33. Nasser $M$, Ueffing $E$, Welch $V$, Tugwell $P$. An equity lens can ensure an equity-oriented approach to agenda setting and priority setting of Cochrane Reviews. J Clin Epidemiol. 2013;66(5):511-21 [cited 2018 Nov 29] Available from: http://www.ncbi.nlm.nih.gov/pubmed/23477991.

34. Fleurence R, Selby JV, Odom-Walker K, Hunt G, Meltzer D, Slutsky JR, et al. How The Patient-Centered Outcomes Research Institute Is Engaging Patients And Others In Shaping Its Research Agenda. Health Aff. 2013;32(2): 393-400 [cited 2018 Nov 29] Available from: http://www.healthaffairs.org/ doi/10.1377/hlthaff.2012.1176.

35. Chalmers I, Bracken MB, Djulbegovic B, Garattini S, Grant J, Gülmezoglu AM, et al. How to increase value and reduce waste when research priorities are set. Lancet. 2014;383(9912):156-65 [cited 2018 Nov 29] Available from: http://www.ncbi.nlm.nih.gov/pubmed/24411644.

36. Donabedian A. Evaluating the quality of medical care. Milbank Q. 2005;83(4): 691-729 [cited 2018 Nov 29] Available from: http://www.ncbi.n/m.nih.gov/ pubmed/16279964.

37. Thomas J, Harden A. Methods for the thematic synthesis of qualitative research in systematic reviews. BMC Med Res Methodol. 2008;8(1):-45 [cited 2018 Nov 29] Available from: http://www.ncbi.nlm.nih.gov/pubmed/18616818.

38. Moher D, Liberati A, Tetzlaff J, Altman DG, PRISMA Group. Preferred Reporting Items for Systematic Reviews and Meta-Analyses: The PRISMA Statement. PLoS Med. 2009;6(7):e1000097 [cited 2019 Jan 17] Available from: http://www.ncbi.n/m.nih.gov/pubmed/19621072.

39. The Joanna Briggs Institute. Joanna Briggs institute Reviewer's manual. The Joanna Briggs Institute 2014.

40. Joanna Briggs Institute. Checklist for Qualitative Research [Internet]. 2017 [cited 2019 Jun 21]. Available from: http://joannabriggs.org/research/criticalappraisal-tools.htmlwww.joannabriggs.org

41. The Joanna Briggs Institute. Checklist for systematic reviews and Research syntheses. Joanna Briggs Inst 2016;

42. Joanna Briggs Institute. Critical Appraisal Checklist for Analytical Cross Sectional Studies. Critical appraisal tools. 2017.

43. Canadian Cancer Research Alliance. Pan-canadian framework for palliative and end-of life care research. 2017 [cited 2019 May 30]. Available from: http://www. virtualhospice.ca/Assets/PEOLC_Report_EN(1)_20170605131142.pdf
44. Shipman C, Gysels M, White P, Worth A, Murray SA, Barclay S, et al. Improving generalist end of life care: National consultation with practitioners, commissioners, academics, and service user groups. BMJ. 2008; (7674):337, 848-51 [cited 2019 may 30] Available from: http://www.ncbi.nlm. nih.gov/pubmed/18829640.

45. Sullivan R, Ugalde A, Sinclair C, Breen LJ. Developing a Research Agenda for Adult Palliative Care: A Modified Delphi Study. J Palliat Med. 2018;22(5):4808 [cited 2019 may 30] Available from: http://www.ncbi.nlm.nih.gov/ pubmed/30461347.

46. Riffin C, Pillemer K, Chen EK, Warmington M, Adelman RD, Reid MC. Identifying Key Priorities for Future Palliative Care Research Using an Innovative Analytic Approach. Am J Public Health. 2015;105(1):e15-21 [cited 2018 Nov 29] Available from: http://www.ncbi.nlm.nih.gov/pubmed/253 93169.

47. Diffin J, Spence M, Spencer R, Mellor P, Grande G. Involving healthcare professionals and family carers in setting research priorities for end-of-life care. Int J Palliat Nurs. 2017;23(2):56-9 [cited 2018 Nov 14] Available from: http://www.magonlinelibrary.com/doi/10.12968/ijpn.2017.23.2.56.

48. Perkins P, Booth S, Vowler SL, Barclay S. What are patients' priorities for palliative care research? - a questionnaire study. Palliat Med. 2008;22(1):712 [cited 2018 Nov 29] Available from: http://www.ncbi.nlm.nih.gov/ pubmed/18216073.

49. Pillemer K, Chen EK, Riffin C, Prigerson H, Reid MC. Practice-Based Research Priorities for Palliative Care: Results From a Research-toPractice Consensus Workshop. Am J Public Health. 2015;105(11):2237-44 [cited 2018 Nov 29] Available from: http://www.ncbi.nlm.nih.gov/ pubmed/26378859.

50. Powell RA, Harding R, Namisango E, Katabira E, Gwyther L, Radbruch L, et al. Palliative Care Research in Africa: Consensus Building for a Prioritized Agenda. J Pain Symptom Manage. 2014;47(2):315-24 [cited 2018 Nov 29] Available from: http://www.ncbi.nlm.nih.gov/pubmed/23 870840

51. Donabedian A. The quality of care. How can it be assessed? JAMA. 1988; 260(12):1743-8 [cited 2018 Nov 29] Available from: http://www.ncbi.nlm.nih. gov/pubmed/3045356

52. Kamal AH, Gradison M, Maguire JM, Taylor D, Abernethy AP. Quality Measures for Palliative Care in Patients With Cancer: A Systematic Review. J Oncol Pract. 2014;10(4):281-7 [cited 2018 Nov 29] Available from: http:// ascopubs.org/doi/10.1200/JOP.2013.001212.

53. Byock I, Norris K, Curtis JR, Patrick DL. Improving end-of-life experience and care in the community: a conceptual framework. J Pain Symptom Manage. 2001;22(3):759-72 [cited 2018 Nov 29] Available from: http://www.ncbi.nlm. nih.gov/pubmed/11532589.

54. Bainbridge D, Brazil K, Krueger P, Ploeg J, Taniguchi A. A proposed systems approach to the evaluation of integrated palliative care. BMC Palliat Care. 2010;9(1):-8 [cited 2018 Nov 29] Available from: http://bmcpalliatcare. biomedcentral.com/articles/10.1186/1472-684X-9-8.

55. Chalmers I, Glasziou P. Avoidable waste in the production and reporting of research evidence. Lancet. 2009:374(9683):86-9 [cited 2019 may 30] Available from: http://www.ncbi.nlm.nih.gov/pubmed/19525005.

56. Glasziou P, Chalmers I. Research waste is still a scandal -an essay by Paul Glasziou and lain Chalmers. BMJ [Internet]. 2018 Nov 12 [cited 2019 Jun 21]; 363:k4645. Available from: https://www.bmj.com/content/363/bmj.k4645/ related

57. Perfetto EM, Oehrlein EM, Boutin M, Reid S, Gascho E. Value to Whom? The Patient Voice in the Value Discussion. Value Heal. 2017;20(2):286-91 [cited 2019 Jun 21] Available from: http://www.ncbi.nlm.nih.gov/pubmed/28237211.

58. Stewart RJ, Caird J, Oliver K, Oliver S. Patients' and clinicians' research priorities. Heal Expect. 2011;14(4):439-48 [cited 2019 Jun 21] Available from: http://www.ncbi.n/m.nih.gov/pubmed/21176014.

59. Brighton LJ, Pask S, Benalia H, Bailey S, Sumerfield M, Witt J, et al. Taking patient and public involvement online: qualitative evaluation of an online forum for palliative care and rehabilitation research. Res Involv Engagem. 2018:4(1):14 [cited 2018 Nov 29] Available from: http://www.ncbi.nlm.nih. gov/pubmed/29744131.

60. Kaasa S, Hjermstad MJ, Loge JH. Methodological and structural challenges in palliative care research: How have we fared in the last decades? Palliat Med. 2006;20(8):727-34 [cited 2018 Nov 29] Available from http://www.ncbi. nlm.nih.gov/pubmed/17148527.

61. Thompson J, Barber R, Ward PR, Boote JD, Cooper CL, Armitage CJ, et al. Health researchers' attitudes towards public involvement in health research. 
Heal Expect. 2009;12(2):209-20 [cited 2019 Jun 21] Available from: http:// www.ncbi.nlm.nih.gov/pubmed/19392833.

62. Ward PR, Thompson J, Barber R, Armitage CJ, Boote JD, Cooper CL, et al. Critical perspectives on 'consumer involvement' in health research. J Sociol. 2010;46(1):63-82 [cited 2019 Jun 21] Available from: http://journals.sagepub. com/doi/10.1177/1440783309351771.

63. Terry RF, Charles E, Purdy B, Sanford A. An analysis of research prioritysetting at the World Health Organization - How mapping to a standard template allows for comparison between research priority-setting approaches. Heal Res Policy Syst. 2018;16:116.

64. Jünger S, Payne SA, Brine J, Radbruch L, Brearley SG. Guidance on Conducting and REporting DElphi Studies (CREDES) in palliative care: Recommendations based on a methodological systematic review. Palliat Med. 2017;31(8):684-706 [cited 2018 Nov 29] Available from: http://www. ncbi.nlm.nih.gov/pubmed/28190381.

65. Lynch T, Connor S, Clark D. Mapping Levels of Palliative Care Development: A Global Update. J Pain Symptom Manage [Internet]. 2013 Jun [cited 2018 Nov 29];45(6):1094-106. Available from: http://www.ncbi.nlm.nih.gov/ pubmed/23017628.

66. Curiale V. World-wide literature survey on geriatric palliative medicine Eur Geriatr Med [Internet]. 2011 Feb 1 [cited 2019 Jun 21];2(1):6-11. Available from: https://www.sciencedirect.com/science/article/pii/S1 878764910002925

67. Clark J, Gardiner C, Barnes A. International palliative care research in the context of global development: a systematic mapping review. BMJ Support Palliat Care. 2018;8(1):7-18 [cited 2018 Apr 19] Available from: http://spcare. bmj.com/content/8/1/7.

68. Nobel C. Why Global Health Researchers Should Climb Down From the Ivory Tower [Internet]. 2014 [cited 2019 Jun 21]. Available from: https:// www.forbes.com/sites/hbsworkingknowledge/2014/08/06/why-globalhealth-researchers-should-climb-down-from-the-ivory-tower/\#4df83e821 b27

\section{Publisher's Note}

Springer Nature remains neutral with regard to jurisdictional claims in published maps and institutional affiliations.

Ready to submit your research? Choose BMC and benefit from:

- fast, convenient online submission

- thorough peer review by experienced researchers in your field

- rapid publication on acceptance

- support for research data, including large and complex data types

- gold Open Access which fosters wider collaboration and increased citations

- maximum visibility for your research: over $100 \mathrm{M}$ website views per year

At $\mathrm{BMC}$, research is always in progress.

Learn more biomedcentral.com/submissions 